\title{
ПРАВОВА ПРИРОДА ЗВІЛЬНЕННЯ ВІД ВІДБУВАННЯ ПОКАРАННЯ З ВИПРОБУВАННЯМ
}

\author{
Резніченко Г. С., Мурадян Г. Р.
}

Серед кримінально-правових підстав інституту «Звільнення від покарання та його відбування» закріплено Звільнення від відбування покарання з випробуванням. Поняття "випробування", яке характерне для такого виду звільнення від відбування покарання та закріплено в $\mathrm{cm} . \mathrm{cm} .75,76$, 77, 78, 79 Кримінального кодексу України, застосовується досить часто, проте законодавчого визначення поняття в кримінальному законодавстві не закріплено. Думки вчених стосовно змісту й правової природи звільнення від відбування покарання з випробуванням надто різняться між собою.

Авторами статті проведено аналіз історичних аспектів виникнення інституту звільнення від відбування покарання з випробуванням. Визначено, що сучасний зміст звільнення від відбування покарання 3 випробуванням $\epsilon$ поєднанням змісту умовного засудження та звільнення від відбування покарання з відстрочкою, які були підставами звільнення від відбування покарання за попереднім кримінальним законодавством.

Проаналізовано наукові позиції вчених-криміналістів, які в різні роки досліджували «Звільнення від відбування покарання з випробуванням» із різних позицій. Доведено, що серед науковців, які досліджували питання, немає одностайності стосовно правової природи й сутності такого виду звільнення від відбування покарання. Діапазон наукових позицій починається від ототожнення звільнення від відбування покарання з випробуванням і кримінального покарання до формування в кримінальному законодавстві самостійного правового інституту «Пробація», який буде передбачати правові підстави застосування звільнення від відбування покарання з випробуванням і наслідки застосування такого виду звільнення від відбування покарання. 3 урахуванням надбань сучасної науки кримінального права, на підставі результатів дослідження такого інституту вченими-кримінологами наведено власне бачення змісту звільнення від відбування покарання з випробуванням.

Ключові слова: покарання, звільнення від покарання з випробуванням, засуджений, кримінальне право, виправлення, кримінальне правопорушення.

(c) Резніченко Г. С., Мурадян Г. Р., 2020
Reznichenko H. S., Muradyan G. R. The legal nature of release from serving a sentence with probation

Among the criminal-legal bases of the institute "Release from punishment and its serving" is fixed Release from serving punishment with probation. The concept of "trial", which is characteristic of this type of release from serving a sentence, and is enshrined in articles 75 , 76, 77, 78, 79 of the Criminal Code of Ukraine is used quite often, but the legislative definition of this concept is not enshrined in criminal legislation. The opinions of scientists regarding the content and legal nature of exemption from serving a sentence with probation differ too much among themselves.

The authors of the article analyzed the historical aspects of the emergence of the institution of exemption from serving a sentence with probation. It was determined that the modern content of release from serving a sentence with probation is a combination of the content of a conditional sentence and release from serving a sentence with a deferral, which were the grounds for release from serving a sentence under the previous criminal law.

Analyzed the scientific positions of scientists-forensic scientists, who in different years investigated "Release from serving a sentence with probation" from different positions. It has been proved that among scientists who have investigated this issue there is no unanimity regarding the legal nature and essence of this type of release from punishment. The range of scientific positions starts from the identification of release from serving a sentence with probation and criminal punishment to the formation in the criminal legislation of an independent legal institution "Probation", which will provide for the legal grounds for the application of release from serving a sentence with testing and the consequences of applying this type of release from serving a sentence. Taking into account the achievements of modern science of criminal law, based on the results of the research of this institute, scientistscriminologists presented their vision of the content of release from serving a sentence with a test.

Keywords: punishment, release from punishment, convicted person, criminal law, corrections, criminal offense.

Постановка проблеми та іï актуальність. Кримінальне законодавство України передбачає інститут звільнення від покарання та його 
відбування, де серед підстав застосування такого інституту передбачено звільнення від відбування покарання з випробуванням. Закріплюючи поняття «випробування» в ст. ст. 75, 76, 77, 78, 79 Кримінального кодексу України, законодавець не надає тлумачення такого поняття.

Тож визначення сутності й змісту звільнення від відбування покарання 3 випробуванням, поняття «випробування» має неабияке теоретичне й практичне значення для кримінального права.

Аналіз останніх досліджень і публікацій. Особливості поняття «випробування» досліджувалися в працях О.М. Звенигородського, І.Г. Богатирьова, А.О. Клевцова, О.О. Книженко, О.В. Козаченка, Є.С. Назимко, Є.О. Письменського, Ю.О. Фідрі, В.П. Філонова, М.І. Хавронюка, А.М. Ященка, В.О. Меркулової та інших. Проте кожний автор наводив власне бачення сутності цих понять.

Метою статті $\epsilon$ дослідження правової природи поняття «випробування», визначення його змісту.

Виклад основного матеріалу. Дослідження правової природи будь-якого інституту починається зі з'ясування історії його розвитку. Умовне засудження як міжгалузевий правовий інститут давно зайняло місце в системі призначення та реалізації кримінальних покарань, хоча його історія налічує трохи понад ста двадцяти років. Перші відомості про появу умовного засудження належать до середини XIX ст., коли воно вперше було застосовано одним з англійських суддів у Бірмінгемі [1, с. 38]. Остаточно ж такий інститут був закріплений у Великобританії Законом від 1887 р. «Про випробування вперше засуджених» та оформлений Законом від 1907 р. «Про випробування злочинців». У 1888 р. умовне засудження було регламентовано в кримінальному законодавстві Бельгії, а в 1891 р. - у Франції. Так почалося впровадження в кримінальне право інституту умовного засудження, який у ряді країн енергійно розвивався [2, с. 36].

У Кримінальному кодексі (далі - КК) Української Радянської Соціалістичної Республіки (далі УРСР) 1922 р. норми про умовне засудження були розташовані в розділі «Про покарання» [3]. В Основних началах кримінального законодавства Союзу Радянських Соціалістичних Республік (далі - СРСР) і союзних республік 1924 р. умовне засудження було виключено з переліку покарань. Термін «покарання» в Основних началах не вживався, його було замінено на термін «заходи соціального захисту» [4]. КК УРСР 1927 р. передбачав можливість застосування умовного засудження до виправних робіт, а призначені додаткові покарання виконувалися засудженим самостійно [5]. М.Д. Шаргородський писав, що умовне засудження - це встановлений у радянському кримінальному праві особливий порядок виконання покарання, яке полягає в тому, що вирок не виконується, якщо засуджений протягом певного строку не вчинить нового, не менш тяжкого злочину [6, с. 47]. Ст. 38 Основ кримінального законодавства Союзу РСР і союзних республік 1958 р. ще більше розширила обсяг застосування умовного засудження, а саме передбачалося, що, якщо суд дійде до переконання про недоцільність відбуття винним призначеного йому позбавлення волі або виправних робіт, він міг прийняти рішення про умовне засудження з обов'язковою вказівкою у вироку мотивів умовного засудження. Умовою неприведення вироку до виконання визначалося невчинення засудженим іншого умисного злочину. Крім штрафу, ніякі додаткові покарання не застосовувалися [7]. КК 1960 р. умовне засудження визначав як особливий порядок виконання вироку, передбачаючи, що під час призначення покарання у виді позбавлення волі чи виправних робіт суд, враховуючи обставини справи й особистість винного, дійде переконання про недоцільність відбування винним призначеного покарання, він може ухвалити умовне незастосування покарання [8].

У 1977 р. до КК 1960 р. були внесені зміни, згідно з якими було запроваджено відстрочку виконання вироку, яка багато в чому нагадувала умовне засудження, але могла застосовуватися до особи, засудженої вперше [9]. 3 прийняттям чинного КК 2001 р. умовне засудження та відстрочка виконання вироку були трансформовані у звільнення від відбування покарання з випробуванням [10].

Натепер звільнення від відбування покарання з випробуванням полягає в тому, що суд виносить обвинувальний вирок у справі, призначає засудженому конкретний вид покарання та визначає його розмір, але доходить висновку про можливість виправлення засудженого без відбування покарання, тобто не приводить вирок у виконання, за умови виконання засудженим упродовж іспитового строку певних обов'язків, які покладаються судом на особу, звільнену від відбування покарання з випробуванням. Можливість застосування звільнення від відбування покарання з випробуванням обмежена: по-перше, певними видами покарання, до яких належать виправні роботи, службові обмеження для військовослужбовців, обмеження волі, а також позбавлення волі, 
по-друге, можливість застосування звільнення від відбування покарання з випробуванням під час засудження до позбавлення волі можлива тільки за умови, що його строк не перевищує п'яти років.

Підставою для застосування звільнення від відбування покарання з випробуванням $€$ визнання судом можливості виправлення засудженого без реального відбування призначеного покарання. Такий висновок ґрунтується на підставі врахування тяжкості кримінального правопорушення, особи винного й інших обставин справи. До інших обставин справи, які можуть враховуватися судом під час застосування звільнення від відбування покарання, належать обставини, які пом'якшують або обтяжують покарання.

Під час звільнення від відбування покарання 3 випробуванням у вироку суду вказується не тільки строк покарання, але й іспитовий строк, який починає обчислюватися 3 моменту проголошення вироку суду. Тривалість іспитового строку, протягом якого особа повинна довести своє виправлення, становить від одного до трьох років. Цей строк законом не диференціюється залежно від виду й міри покарання. Проте суд під час встановлення тривалості іспитового строку на свій розсуд може врахувати ступінь тяжкості кримінального правопорушення, особу винного, вид і міру покарання та інші обставини [11, с. 165].

Нагляд за особами, звільненими від відбування покарання з випробуванням, здійснюється уповноваженим органом із питань пробації за місцем проживання, роботи або навчання засудженого, а щодо засуджених військовослужбовців - командирами військових частин.

Відповідно до ст. 76 КК України на період іспитового строку на особу, звільнену від відбування покарання з випробуванням, суд може покласти обов'язки, які залежно від ступеня тяжкості й виду кримінального правопорушення, віку засудженої особи, іï стану здоров'я, трудового віку можна поділити на дві групи:

1) періодично з'являтися для реєстрації до уповноваженого органу з питань пробації; повідомляти уповноважений орган із питань пробації про зміну місця проживання, роботи або навчання; на осіб, засуджених за кримінальні правопорушення, пов'язані з домашнім насильством, суд може покласти інші обов'язки й заборони, що передбачені для осіб, які вчинили домашнє насильство;

2) попросити публічно або в іншій формі пробачення в потерпілого; не виїжджати за межі України без погодження з уповноваженим органом із питань пробації; працевлаштуватися або за направленням уповноваженого органу з питань пробації звернутися до органів державної служби зайнятості для реєстрації як безробітного й працевлаштуватися, якщо йому буде запропоновано відповідну посаду (роботу); виконувати заходи, передбачені пробаційною програмою; пройти курс лікування від розладів психіки й поведінки внаслідок вживання психоактивних речовин або захворювання, що становить небезпеку для здоров'я інших осіб; дотримуватися встановлених судом вимог щодо вчинення певних дій, обмеження спілкування, пересування та проведення дозвілля [10].

Упродовж іспитового строку суд за поданням уповноваженого органу з питань пробації може змінювати обов'язок (обов'язки), визначені у вироку суду. Підставою для цього є обставини, які не залежать від засудженого й позбавляють його можливості виконати покладені на нього обов'язки.

Після закінчення іспитового строку засуджений, який виконав покладені на нього обов'язки й не вчинив нового кримінального правопорушення, за поданням уповноваженого органу з питань пробації звільняється судом від призначеного йому покарання, нагляд припиняється та засуджений знімається з обліку в зазначеному органі.

Якщо засуджений не виконує обов'язки, покладені на нього судом, або систематично вчиняє правопорушення, що тягнуть за собою адміністративні стягнення та свідчать про його небажання стати на шлях виправлення, уповноважений орган із питань пробації вносить до суду подання про скасування звільнення від відбування покарання з випробуванням і спрямовування засудженого для відбування призначеного покарання.

Традиційно звільнення від відбування призначеного судом покарання з випробуванням розглядається в доктрині кримінального права як форма реалізації кримінальної відповідальності [12, с. 235]. Проте вчені-правники по-різному тлумачать це поняття.

В.П. Філонов та Є.С. Назимко пишуть, що, хоча за національним кримінальним законодавством звільнення від відбування покарання 3 випробуванням не $\epsilon$ покаранням, воно має всі його ознаки, а також створює певний режим відбування та реалізації схожого на покарання виду кримінально-правового примусу [13, с. 186]. Ю.О. Фідря вважає, що, не зважаючи на окремі спільні риси, звільнення від відбування покарання з випробуванням володіє не всіма ознаками 
покарання. Покарання $\epsilon$ найсуворішим, крайнім видом не лише заходів кримінально-правового впливу, але й заходів державного примусу в цілому. Крім того, покарання можна розглядати як своєрідний універсальний інструмент впливу на особу, яка вчинила будь-який злочин, тоді як інститут випробування застосовується за наявності певних умов і підстав за вчинення окремих видів злочинів [14]. На думку М.І. Хавронюка, звільнення від відбування покарання з випробуванням $\epsilon$ певним проміжним кримінально-правовим заходом між покаранням і звільненням від покарання. 3 одного боку, воно має ознаки покарання (зокрема, це примусовий захід, який застосовується від імені держави за вироком суду й полягає в передбаченому законом обмеженні прав і свобод засудженого). 3 іншого боку, воно не $\epsilon$ власне покаранням, оскільки як покарання не передбачене в списку видів покарань, визначеному, наприклад, у ст. 51 КК України, й прямо віднесене КК України (ст. ст. 75-78 КК України) до видів звільнення від покарання [15, с. 344]. Надалі вчений зауважив, що звільнення від відбування покарання з випробуванням $є$ аналогом пробації [16, с. 298]. Звільнення від відбування покарання з випробуванням, як вважають О.О. Рибак і Д.В. Ягунов, є складовою частиною пробації. На думку вчених, інститут пробації ширший у виборі засобів і способів виправлення та ресоціалізації особи, що вчинила злочин [17]. О.О. Книженко доходить висновку про необхідність (доцільність) і можливість виокремлення в Загальній частині КК норм, які врегульовують порядок і наслідки застосування звільнення від відбування покарання з випробуванням, у самостійний інститут «Пробація», під яким слід розуміти систему випробування, що застосовується судом щодо осіб, які можуть виправитися без відбування призначеного основного покарання [18, с. 15]. А.О. Клевцов, вважає, що наявна в кримінальному законодавстві України назва «звільнення від відбування покарання з випробуванням» $є$ суперечливою, оскільки заперечує гуманістичний характер такого інституту, створює відчуття його репресивності. Крім того, «випробування» більше стосується техніки, механізмів і не прийнятне щодо людини. Термін «звільнення від відбування покарання з умовою» більше відповідає сутності такого виду звільнення від відбування покарання, зокрема його юридичній природі, охоплює всі його структурні елементи [19, с. 177]. А.В. Андреєв вважає, що прийнятніше було б називати звільнення від відбування покарання з випробуванням умовним звільненням від покарання. Зважаючи на сказане, доцільно ст. 75 КК України назвати «Умовне звільнення від покарання», а в самому тексті статті словосполучення «звільнення від відбування покарання з випробуванням» замінити на «умовне звільнення від покарання [20, с. 238].

Кожна з позицій вчених заслуговує на увагу. На нашу думку, звільнення від відбування покарання з випробуванням не можна ототожнювати з покаранням, не зважаючи на те, що воно містить певні ознаки кримінального покарання. Це форма реалізації кримінальної відповідальності особи за вчинене кримінальне правопорушення, яка не обов'язково повинна тягти за собою застосування кримінального покарання. 3 цього приводу вірною $\epsilon$ думка професора В.О. Меркулової, що вже сам факт публічного засудження, визначення обсягу кримінальної репресії, виду й терміну покарання (незалежно віл того, чи буде воно реально виконуватися) забезпечує певною мірою виконання цілей покарання [21, с. 115].

Висновки. У кримінально-правових нормах інституту «Звільнення від покарання та його відбування» поняття «випробування» застосовується досить часто, проте законодавчого визначення такого поняття в кримінальному законодавстві не закріплено. Думки вчених стосовно змісту й правової природи поняття надто різняться між собою. Вважаємо, що звільнення від відбування покарання з випробуванням не можна ототожнювати з кримінальним покаранням. Це форма реалізації кримінальної відповідальності особи, яка передбачає засудження особи, осуд вчиненого нею діяння з боку держави й суспільства, але звільнення особи від реального відбування покарання. Проте недотримання засудженим вимог поведінки під час іспитового терміну, несумлінне виконання покладених обов'язків тягне скасування звільнення від відбування покарання та спрямовування засудженого для реального відбування призначеного покарання.

\section{Література}

1. Хаитжанов А. История возникновения и развития института условного осуждения. Уголовно-исполнительная система: право, экономика, управление. 2008. № 2. С. 34-45.

2. Ткачевский Ю.М. Понятие условного осуждения. Вестник МГУ. 2010. № 3. С. 36.

3. Уголовный кодекс УССР в редакции 1922 г. С изм. и доп. по 1-е ноября 1924. Харьков : Юрид. изд. Наркомюста УССР, 1925. 104 с.

4. Сборник документов по истории уголовного законодательства СССР и РСФСР 1917-1952 гг. / 
Под ред. И.Т. Голякова. Москва : Гос. из-во юрид. лит., 1953. 460 с.

5. Уголовный кодекс УССР в редакции 1927 г. С изм. по 1-е июня 1928 г. 3-е офиц. изд. Харьков : Юрид. изд., 1928. 120 с.

6. Шаргородский М.Д. Вина и наказание в советском уголовном праве. Москва : Юрид. изд-во НКЮ CCCP, 1945. 56 c.

7. Відомості Верховної Ради СРСР. 1959. № 1. Ст. 6.

8. Відомості Верховної Ради СРСР. 1969. № 50. Ст. 388.

9. Відомості Верховної Ради СРСР. 1977. № 14. Ст. 128.

10. Кримінальний кодекс України : Закон України від 5 квітня 2001 року № 2341-ІІІ / Верховна Рада України. URL: http://zakon4.rada.gov.ua/laws/ show/2341-14/page3 (дата звернення: 11.02.2021).

11. Науково-практичний коментар Кримінального кодексу України. 3-тє вид., переробл. та доповн. / за ред. М.І. Мельника, М.І. Хавронюка. Київ : Атіка, 2003. 1056 c.

12. Павлова Т.О. Звільнення від відбування покарання з випробуванням як примусовий захід кримінально-правового характеру. Правова держава. 2016. № 21. С. 234-239.

13. Філонов В.В., Назимко Є.С. Реформування інституту звільнення від відбування покарання 3 випробуванням у світлі сучасних тенденцій гуманізації пенальної політики України. Право України. 2010. № 3. С. 184-189.

14. Фідря Ю.О. Стан та перспективи вдосконалення інституту звільнення від відбування покарання 3 випробуванням. URL: http: / /historylaw.eenu.edu.ua/ publ/2_92_2014/rozd (дата звернення: 10.02.2021).

15. Хавронюк M.І. Кримінальне законодавство України та інших держав континентальної Європи: порівняльний аналіз, проблеми гармонізації : монографія. Київ : Юрисконсульт, 2006. 1048 с.
16. Дудоров О.О., Хавронюк М.І. Кримінальне право : навчальний посібник. Київ : Ваіте, 2014. 944 c.

17. Рибак О.О., Ягунов Д.В. Співвідношення між інститутом звільнення від відбування покарання з випробуванням та інститутом пробації. URL: http: / /www.stattionline.org.ua/politologiya/30politika/1800-pivvidnoshennya (дата звернення: 10.02.2021).

18. Книженко О.О. Звільнення від відбування покарання з випробуванням за кримінальним правом україни : автореф. дис. ... канд. юрид. наук : 12.00.08. Харків, 2003. 20 с.

19. Клевцов А.О. Звільнення від відбування покарання з випробуванням неповнолітніх за кримінальним законодавством України : дис. ... канд. юрид. наук : 12.00.08. Дніпропетровськ, 2009. 210 с.

20. Андреєв А.В. Законотворчі та правозастосовні проблеми звільнення від покарання з випробуванням. Науковий вісник Львівського державного університету внутрішніх справ. Серія юридична. 2012. № 4. C. 236-245.

21. Меркулова В.О., Гритенко О.А., Резніченко Г.С. Звільнення від відбування покарання вагітних жінок та жінок, які мають малолітніх дітей : монографія. Одеса : ОДУВС, 2015. 286 с.

Резніченко Г. С., кандидат юридичних наук, доцент, доцент кафедри кримінального права та кримінологіі Одеського державного університету внутрішніх справ

Мурадян Г. Р., аспірант кафедри кримінального права та кримінології Одеського державного університету внутрішніх справ 